\title{
9. Developing the African Union Transitional Justice Policy: an assemblage perspective ${ }^{1}$
}

\section{Ulrike Lühe}

\section{INTRODUCTION}

The politics of knowledge production in transitional justice has started coming under increased scrutiny, with a focus on the transfer of knowledge and norms between and within contexts, and on the North-South dynamics and inequalities that shape the global politics of knowledge in the field. Debates around the nature and use of expertise which have emerged from the literatures on knowledge production and transfer, and the norms diffusion literature, have largely discussed expertise in the hands of a select number of international, professional actors (Lefranc and Vairel, 2013; Brehm et al., 2019; Ní Aoláin, 2015; Mouralis, 2013). While the literature has emphasized the preference that the field of transitional justice shows for legalistic, technical and thus apolitical knowledge (Subotic, 2012; Lefranc and Vairel, 2013; Oomen, 2005), it continues to assume that this knowledge is held by a small number of actors who then transfer it to policy-makers and practitioners in contexts of unequal power relations. This assumes that expertise is not only the property of a few select actors but that it is also stable. By focusing on international non-governmental organizations (NGOs) and the technical expertise rooted in lessons learnt and best practices, the literature also furthers an assumption that policy processes require, and are built on, one type of expertise - no matter the contextual factors or the changing nature of such processes over time. What is emphasized then is legal, technical, academic and thematic knowledge over networks, tacit knowledge, context and political knowledge. This betrays not only the political nature of policy-making in general, but it also reduces transitional justice to a technical response to conflict and transition, rather than seeing it as a political renegotiation taking place over time and between varied actors.

The transitional justice literature that focuses on the North-South dynamics and inequalities in transitional justice expertise in particular highlights 
the extractive dynamics and unequally distributed agenda-setting power in the field. On the one side it emphasizes 'transitional justice entrepreneurs' (Madlingozi, 2010: 213), well-travelled international experts who 'theorize the field; set the agenda; legitimize what constitute appropriate transitional justice norms and mechanisms; influence the flow of financial resources; assist governments in transition; invite, collaborate with and capacitate "relevant" local NGOs and "grassroots organizations", (ibid.: 225). On the other side it posits national and local actors in the Global South whose priorities are overwritten by international actors in the name of a moralistic and normative human rights agenda and victims on whose behalf actors speak (ibid.). Many of these studies speak in one way or another to the North-South discrepancies in terms of access, resources, power, influence and expertise. ${ }^{2}$ However, the practices of knowledge production and expertise within and among transitional justice actors in the South, be they academics, policy-makers or practitioners, have rarely been researched. ${ }^{3}$

This chapter seeks to address both of the gaps outlined above. Firstly, it contributes to a more complex understanding of the use of expertise in policy processes by going beyond a focus on one actor group - international NGOs - and tracing how the shifting needs and circumstances of a policy process change what expertise is required, and thus what expertise means. In doing so I show that expertise is not a stable property of some professional, international actors, but rather a resource that is strategically assembled by different stakeholders in order to meet the complex needs of policy-making. Secondly, it contributes a unique perspective by not focusing on international NGOs or the inequality of North-South interactions, but on a policy process and the making and shaping of expertise within and among stakeholders located in Africa. This chapter will thus explore the strategic assembling of different types of expertise that were required for and employed in the development of the African Union Transitional Justice Policy (AUTJP). It draws on practice and assemblage theories from the broader field of International Relations (IR). As the analysis in this chapter shows, the knowledge drawn on for the making of the AUTJP is not a static body of knowledge, but rather has been assembled by and from a range of stakeholders including, among others, expert consultants and a broader consultation process - activities that are conceptualized as epistemic practices.

At the core of this policy process, and driving most of this assemblage process, were the South African Center for the Study of Violence and Reconciliation (CSVR) and, in the early stages, its partners who have formalized their partnership in the African Transitional Justice Research Network (ATJRN). Based on the research and reflections they had conducted in the mid-2000s on various African transitional justice experiences, they began an advocacy effort aimed at the African Union (AU) for it to develop and adopt 
a continental transitional justice policy. The CSVR in particular initiated the process, provided the resources, expertise and momentum required to see it through, and ensured the adoption of the policy through its sustained advocacy. Formally, the CSVR acted as the coordinator of the policy process. Throughout the process, however, it drew in outside expertise. It is this assembling of expertise which is the focus of my analysis.

This chapter thus provides an account of the way expertise is assembled for the purpose of developing a continental policy in a policy field that is at once dominated by technical approaches and highly political, based on models and best practices and highly complex and contextually specific knowledge. This analysis is based on a review of the various written outputs that were produced in this policy process as well as 60 key informant interviews that were conducted between June and December 2018 in South Africa, Addis Ababa/ Ethiopia, Nairobi/Kenya, Arusha/Tanzania and via Skype, and in February 2019 in Addis Ababa. Interviewees included key stakeholders involved in the policy process from civil society and the African Union Commission (AUC) as well as transitional justice experts who have not been involved in the process but have been observing it. Additional informal conversations helped shape my understanding of the process, its evolution and context.

I will proceed by discussing my conceptual framework which centers on assemblage and practice theories borrowed from IR, before providing an overview of the AUTJP. The core of this chapter then discusses two practices that were key to the strategic assemblage of expertise that was built throughout the making of the continental policy - the use of experts and consultants to review and revise the policy and a broad process of consultation meetings and workshops. I focus on those practices that show most clearly how the CSVR relies not only on its own expertise but also draws on an assemblage of experiences, disciplinary backgrounds and types of expertise. These are also the practices that help co-create knowledge and legitimacy thus (re-)enforcing the expert status of the involved stakeholders. This analysis holds important insights for both transitional justice and IR, for in both fields the knowledge production and policy-making practices of African governmental, non-governmental and regional organizations (such as the AU and Southern-based research networks) remain vastly under-researched. ${ }^{4}$ Furthermore, the AUTJP is only the second holistic, continental transitional justice policy ${ }^{5}$ that has been developed. Its analysis can thus provide insights for the future nature and making of such policies. Lastly, this is a unique process in that the key stakeholders have tried to almost exclusively rely on African expertise, which runs contrary to the often-expressed assumption that international (read Northern) expertise is prevalent (and necessary) in Southern policy processes (for critical discussions on this see Ní Aoláin, 2015; Fletcher and Weinstein, 2018a, 2018b; Oduro and Nagy, 2014). 


\section{ASSEMBLAGES OF KNOWLEDGE AND EXPERTISE}

In IR the study of expertise and the knowledge-policy nexus has for a long time focused on the agency of experts and expert groups, for example epistemic communities or advocacy coalitions, and on how they exert influence and authority (Haas, 1992; Keck and Sikkink, 1998). Their expertise is thus grounded in the policy-relevant knowledge they hold, produce and distribute. However, considerably less emphasis has been placed on how these actors produce knowledge and how this knowledge gains authority (Bueger, 2015). From there, the focus has shifted towards expertise not as the property of an individual or group, 'but the effect of a process' (Bueger, 2019: 42). If, then, 'expertise is authoritative knowledge at a given decision point' and 'experts are those who/that which communicate(s) this knowledge' (Leander and Wæver, 2019: 2), expertise and expert status are dependent not only on the definition of the problem at hand, but their expert status is also a function of their relations to those who seek their knowledge or upon whom they infer their knowledge. As a consequence, expertise is contingent and experts are defined relationally. This allows for a definition of expertise as 'a social process of stabilizing the authority of a selection of knowledges in relation to a specific problem' (Berling, 2019: 95).

Expertise then is neither static nor bounded by disciplines, but rather is transgressive in that it crosses boundaries between scientific and practical knowledge (Nowotny, 2000) with professional experience being equally valuable as scientific knowledge. It is unstable and uncertain (Leander and Wæver, 2019) as continuous challenges make constant review and revision a requirement which in turn renders expertise 'provisional' and short-lived (ibid.; Best, 2014). It is in this sense also constantly 'emergent' from tensions and contradictions between different forms of knowledge (ibid.). As it is constantly challenged and emergent, it has to be constantly assembled and maintained (Berling, 2019) and the declaration of the contingent nature of knowledge underlying expertise becomes crucial to the legitimacy of the expertise itself (Jasanoff, 2003). Thus, expertise is simultaneously embattled and maintained, valued and valuable, and constitutive and constituted of not only expert status but also the world in which it operates (Bilgin, 2019). As a consequence, its study needs to involve the study of process and change (Bueger, 2018).

Assemblage theories offer one perspective for doing so as they take account of the 'ever-shifting constellations of actors, institutions, data and forms of expression that make up the expertise' (Leander and Wæver, 2019: 2). As assemblage is 'the continuous work of pulling disparate elements together' $(\mathrm{Li}$, 2007: 264), focusing on it allows an emphasis on both agency and practice. As a 'feature-rich toolbox' that draws on IR realism, international practice theory 
and actor-network theories (Bueger, 2018: 615), assemblage analytics allow us not only to 'finesse questions of agency' (Li, 2007: 265) but also to focus on the practices that actors and agents employ to assemble expertise, that is the 'practical infrastructures through which knowledge is produced and validated' (Bueger, 2015).

Epistemic objects, such as the idea of an African transitional justice, are dependent on 'the deliberations and interpretation of actors, on situational factors, on the political and rhetorical strategies of actors, and potentially on their social and cognitive interests' to become knowable (Knorr-Cetina, 2008: 40). As epistemic objects 'appear to have the capacity to unfold indefinitely' (Knorr-Cetina, 2001: 180) epistemic practices are continuous processes that go beyond 'iterative procedural routines' (Knorr-Cetina, 2001: 186). An epistemic practice, in essence, is a 'particular kind of practice that aims at constructing a distinct epistemic object and manipulating it' (Bueger, 2015: 2). They are practiced by scholars and scientists as much as by expert commissions, planning units, intelligence services, courts or other institutions and actors (ibid.). Practices include 'bodily and mental activities, artifacts, technologies, objects and their use, sayings and doings, representations, concepts and vocabularies, things and machines all of which come together to create structures of meaning' (ibid.: 5). They focus on the 'mundane functioning and everyday maintenance of orders of knowledge' (ibid.: 4). Various practices have been identified in the literature, including practices of problematization, forging alignments, rendering knowledge as technical, authorizing knowledge, managing failures and contradictions, anti-politics, reassembling (Li, 2007); quantification, the use of monitoring groups and special advisers (Bueger, 2015) or the standardization, abstraction, decontextualization and framing work of experts (Ancelovici and Jenson, 2013).

This chapter, in an effort to unpack the expertise that is assembled in the development of the AUTJP, analyzes two types of consultations as epistemic practices that were key in the process of making transitional justice, as an epistemic object, knowable to the AU and especially to AU member states. I will focus on the practices implied in the engagement of key consultants as policy drafters and reviewers, and the continuous use of consultation meetings that shaped much of the process. Cumulatively these provide insight into the types of expertise that were assembled in order to meet the shifting needs and requirements of an evolving policy process while also giving insight into the nature of expertise as more than a static property of actors. 


\section{THE AFRICAN UNION TRANSITIONAL JUSTICE POLICY}

The impetus for the development of the AUTJP came in 2009 from the then newly established Panel of the Wise (PoW), an advisory organ to the AU. In line with its annual priority topics and in response to the increasing need for transitional justice on the African continent and the simultaneously developing tensions with the International Criminal Court (ICC), the PoW focused on the topics of justice, non-impunity, reconciliation and peace among its first priorities (Gomes Porto and Ngandu, 2014). It commissioned Prof. Gilbert Khadiagala from the University of the Witwatersrand and Dr. Comfort Ero, then Head of the South Africa office of the International Center for Transitional Justice (ICTJ), to conduct a study on African transitional justice experiences and to give recommendations to the PoW for further action. The experts' recommendations, among others, included the development of a continental transitional justice policy, to be adopted by the AU in order to guide member states in conceptualizing and implementing transitional justice efforts (Panel of the Wise, 2013).

This was in 2009, around the same time that the ICC had issued its arrest warrant against Omar al-Bashir, then president of the Republic of Sudan, for crimes committed in Darfur (ICC, 2009) and launched investigations into the involvement in the 2007/8 post-election violence, among others, of Uhuru Kenyatta and William Ruto who went on the become Kenya's president and deputy president respectively (Lugano, 2017). Being the first instances in which the ICC investigated sitting heads of state and high-level politicians, considerable resistance was mobilized - notably by African states and through the AU (Ssenyonjo, 2013; Murithi, 2013). ${ }^{6}$ On the one side this did not fare well for any attempts to promote the topic of transitional justice at the AU, on the other it increased the need for the AU and its member states to develop their own approach to accountability and reconciliation, in response to the perceived Western imposition of international criminal justice.

The development of the policy has to be seen not only in light of the contemporary tensions around international criminal justice but also in the context of the AU as the successor institution of the Organization for African Unity (OAU) which was established in 1963 to support independence struggles across the continent (Akokpari, 2008; Gawanas, 2009). This origin explains the strong focus of the OAU on sovereignty and non-interference (Mathews, 2008). Founding the AU was a response to shifting needs on the continent where the possibility of intervention, framed in terms of sovereignty as responsibility (Deng et al., 1996), had become a necessity in light of the events in Somalia in 1992, Rwanda in 1994 and the numerous other conflicts that plagued the 
continent and to which the international community had proved an unwilling, incapable or unsuitable intervention force (Murithi, 2017; Klingebiel, 2005; Mwanasali, 2008). This shift from non-interference to non-indifference has become evident in the AU's increasing, albeit only slowly materializing, efforts to build an African Peace and Security Architecture (APSA) as well as an African Governance Architecture (AGA). Having emerged from the former, the development of the AUTJP was taken over and led by the Department of Political Affairs (DPA) of the AUC, ${ }^{7}$ which is also the secretariat of the AGA.

This brief overview situates the AUTJP not only at the institutional and normative intersection between governance and peace and security, but also in the particular historical context of the $\mathrm{AU}$ as an institution that emerged from a fight for sovereignty and independence but increasingly seeks to foster the principle of sovereignty as responsibility among its members (Deng, 2013; Bah et al., 2014). This contextualization is crucial for understanding the discourses and boundaries within which the process of developing the AUTJP took place. In light of the often interventionist nature of transitional justice processes and mechanisms this creates a frame 'where the policy engagement [was] about building acceptance of the language of transitional justice' (Hugo van der Merwe, quoted in Fletcher and Weinstein, 2018b: 102) ${ }^{8}$ before being able to have substantive thematic discussions. These contextual parameters are crucial as they frame transitional justice not only as a domestic question of how to deal with a violent past, but also a foreign policy and indeed international relations issue for the $\mathrm{AU}$ and its member state. It speaks to global power relations as much as to individual states' post-conflict reconstruction needs and responsibilities. The policy (process) thus had to bridge domestic and foreign policy expertise, speaking equally to local particularities, global transitional justice discourses and the political and technical requirements of transitional justice in Africa.

Around the same time that the PoW took an interest in the topic, the ATJRN had set its eyes on the AU as a target for continental policy advocacy (ATJRN, 2012; Wachira, 2010). The ATJRN emerged out of two research projects. The first was the 'Transitional Justice Governance and Accountability in Africa' project which included the CSVR from South Africa, the Kenya Transitional Justice Working Group, the Refugee Law Project (RLP) in Uganda and the Zimbabwe Lawyers for Human Rights (ZLHR) (Wachira, 2010). This was followed by the ATJRN project which ran from 2006 to 2010. It included the CSVR, ZLHR, RLP, the Center for Democratic Development Ghana, and the Campaign for Good Governance from Sierra Leone (Humphrey and RLP, 2014; Hamber, 2008). The partners were chosen based on their long-standing working relationships and their engagement in transitional justice processes in their home countries (ATJRN, 2012). The ATJRN engaged in joint research activities, reflection processes and publications (ibid.). It also organized the 
African Transitional Justice Institute and other activities which increased its outreach. ${ }^{9}$ ATJRN members furthermore engaged in advocacy in their home countries and targeted the AU for advocacy (Brankovic, 2010). Thus the CSVR (and its partners in the ATJRN) took up the nascent PoW discussions after the Khadiagala and Ero report and engaged in an almost decade-long process of discussions, consultations, reviews and redraftings for which the CSVR served not only as a secretariat but for which it was also the key institution shaping the process and indeed keeping it alive. In 2015 the policy process experienced a considerable setback when the Specialised Technical Committee (STC) on Justice and Legal Affairs, a policy organ of the AU, considered the draft policy for recommendation for adoption to the higher policy organs of the AU, and 'rejected' it. The STC recommended a range of revisions, which reignited the consultation and review process until the policy was adopted by the STC in November 2018 (AU, 2018) and the Summit of the Heads of States and Government, the highest organ of the AU, in February 2019. ${ }^{10}$

The main parties to this policy process and expert assemblage include the DPA as the custodian of the process at the AUC, the AU member states, the CSVR, members of the ATJRN, key experts hired by CSVR (consultants), donors who financed the process, and the many civil society and governmental experts and representatives involved through various consultations. The specific composition of the group changed over time with changing demands, as explored below. However, the CSVR and some of its partners from the ATJRN are an identifiable community of experts that was key at different points during the process as they were critical to initiating the policy engagement (ATJRN, 2012), were represented at several consultation meetings (see e.g. Brankovic, 2010; AU and CSVR, 2011; CSVR, 2012) and authored numerous studies that informed the process directly or indirectly (African Commission for Human and Peoples' Rights, 2019; Songa, 2018; Hanzi, 2010).

In the rest of the chapter I analyze two very different types of consultations as epistemic practices engaged in by the key stakeholders, as these most directly influenced the making of the policy and its knowledge base. As a consequence of having to represent national and local particularities while speaking proficiently to the key discursive frameworks of the AU, the CSVR worked with a network of partners. On the one side it worked with a periodically changing set of consultants and key experts who helped to write and review the policy drafts and on the other side it conducted consultations where a broader range of actors were given a platform to discuss their views on transitional justice and the policy drafts. These epistemic practices were targeted, strategic and tailored to the intended policy outcome while simultaneously broadening the policy process and enabling the assembling of relevant expertise as a strategic resource whenever it was needed. They were, of course, shaped by the broader 
processes and politics of knowledge production globally, in Africa, and in the field of transitional justice.

\section{POLICY REVISIONS: ACADEMIC, PRACTICO-TECHNICAL, GOVERNANCE AND LEGAL EXPERTISE}

Different consultants and experts were brought into the policy process at different times to assess, review and edit policy drafts and to some extent influence their core messages. Firstly, Prof. Gilbert Khadiagala of the University of the Witwatersrand and Dr. Comfort Ero from the ICTJ had been commissioned by the PoW to write a study on 'Peace, Justice and Reconciliation in Africa' (Panel of the Wise, 2013), which included the very first policy proposal. ${ }^{11}$ Comfort Ero left the process after this study. Once the CSVR took over as the secretariat for the consultation and drafting process, Yasmin Sooka, who had worked with the South African and several other truth commissions, was brought in. Sooka was drawn in because she had 'worked on all these big [transitional justice cases like] Sierra Leone, Colombia, Sri Lanka, it made sense to have a lawyer to help in framing the [policy ideas]. Because she's very knowledgeable about TJ issues. ${ }^{12}$ She represents an internationally accepted authoritative voice on transitional justice ${ }^{13}$ and is, simultaneously, an African transitional justice practitioner and a lawyer. She was Deputy Chair of the Human Rights Violations Committee of the Truth and Reconciliation Commission (TRC) in South Africa and responsible for finalizing its report. Later she was one of three international commissioners on the Sierra Leone TRC. In 2010, Sooka was appointed to the Panel of Experts advising the Secretary-General on accountability for war crimes committed in Sri Lanka. In 2016, she was appointed to chair the Commission on Human Rights in South Sudan. Furthermore, 'Sooka has been part of many advisory missions on transitional justice for the United Nations including Afghanistan, Burundi, Kenya, Nepal, and Uganda'. ${ }^{14}$

Sooka provides an interesting case for the blurring of international and 'local,' in this case South African, expertise, and the strategic use of labels in the assigning of expert status. While she was one of the key consultants to advise the development of the AUTJP - a process for which an explicit criteria for participation was the ability to provide 'African expertise' - outside the continent she is variously described as a 'South African human rights lawyer', ${ }^{15}$ a 'leading human rights lawyer"16 or a 'leading international expert in the field of transitional justice. ${ }^{17}$ This highlights how expertise is neither local nor international but is labeled as one or the other as a way of legitimizing and authorizing it for specific purposes. In this particular case her inclusion in the policy process ensured the availability of legally informed, practico-technical 
expertise that is internationally acknowledged and demonstrably African at the same time. Hers is expertise that is rooted in first-hand experience in the running of a truth commission, proficiency in international transitional justice discourses, vast regional and global networks, and an authoritative status that had been inferred through constant interactions with key stakeholders in the field of transitional justice. Making her part of the assemblage arguably contributed not only expertise but also authority to the process.

Khadiagala, on the other hand, had not previously worked on transitional justice. In contrast, he states that he had to do 'a lot of reading [on transitional justice] because that's not really my area of research' and describes himself as a transitional justice sceptic. ${ }^{18}$ His expertise was of a different kind. The political opportunity structure for convincing the AU to continue working on a transitional justice policy was, in the early stages of the process, stacked against the CSVR: in 2010 George Mukundi Wachira, who became one of the key figures in the policy process, observed that at the $\mathrm{AU}$ 'the greatest potential to influence policy on any issue, including on transitional justice, rests at the AU Commission, it being a technical organ involved in the conceptualization and implementation of AU decisions' (Wachira, 2010: 6). However, in the same report he also assessed the African Citizen and Diaspora Directorate which is the secretariat of the Economic, Social and Cultural Council (ECOSOCC) at the AUC and thus the platform dedicated to engagement with civil society, as not being as open as envisaged and '[having] largely excluded active CSOs [civil society organizations] from its engagement' (Wachira, 2010: 6). Despite there being a general interest in the topic, highlighted by the fact that the High Level Panel on Darfur pointed to the importance of transitional justice in 2009 (AU, 2009), and that the 2009 theme for the PoW had been 'impunity, reconciliation and healing,' there were 'bureaucrats at the AU Commission' (Wachira, 2010: 11) making 'working with AU organs [...] not a walk in the park' (ibid.). This was due to 'gatekeepers, individuals bent on keeping their jobs who therefore exhibit hostility towards CSOs perceived to be critical of the AU' (Wachira, 2010: 11). This difficulty was further complicated by the fact that the DPA had not been prone to collaboration with academia or civil society, contrary to the PSD which had had partnerships with think tanks such as the Institute for Security Studies or the Institute for Peace and Security Studies for extended periods of time. ${ }^{19}$ The CSVR turned these odds around when it absorbed Khadiagala, who had been asked to co-author the original study due to his previous working relations with the PoW, ${ }^{20}$ into the process as a key consultant.

Khadiagala recounts how he might not have been a transitional justice expert but someone who "worked with the policy makers and the advocates' ${ }^{21}$ and 'was the only person who had been involved in the first report [to the PoW],' in other words he has a track record with the AU. Furthermore, he had 
written extensively on Africa's international relations, regionalism, peacebuilding, pan-Africanism and the AU (Khadiagala, 2012, 2015, 2018) and is in fact one of the most prolific and most-cited African authors on peace and security in Africa (African Leadership Center, 2018). His expertise is thus not only in a different field but also of a different type, namely academic and in terms of his social capital. I propose that retaining him as a key expert ensured that CSVR's and Yasmin Sooka's practical expertise and critical reflections on transitional justice could be anchored in discourses that speak to the core of the AU and provided individual and institutional networks that permeate the AU. ${ }^{22}$ These were key strategies that ensured access to decision makers in the early stage of the process and paved the way for long-term engagement independently of these individuals. They thus served as a bridge between the core expert community of the CSVR and the ATJRN partners as well as policy-makers.

Khadiagala and Sooka remained as key experts until 2015, when the STC for Justice and Legal Affairs rejected the policy draft and requested that it be revised regarding structure and language (Trust Africa et al., 2015), around some thematic issues (especially gender and youth), ${ }^{23}$ with regards to its position on international criminal justice, ${ }^{24}$ and in terms of the perceived insufficient inclusion of member states in the development of the policy. ${ }^{25}$ The rejection of the policy draft by the STC can be read as a 'switch point' (Li, 2007: 279) in that it 'reshuffl[ed] what is valued [and thus] also change[d] who is an actor' (Leander, 2013: 818) in this process. Now '[a] consultant with policy and legal expertise [was] required to assist in improving the format of the draft policy framework, with particular focus on the structure and language used' (Trust Africa et al., 2015: 5). Based on a suggestion by the DPA, Don Deya, Chairperson of the Pan-African Lawyers Union (PALU), who had already participated in previous consultations and supported other policy processes of the AU, was now commissioned by the CSVR to revise the policy document. ${ }^{26}$ The particular aim was to make it look and feel 'more like a policy document' and less like an academic analysis of transitional justice in Africa. ${ }^{27}$ PALU is one of the foremost voices on legal issues on the continent and seeks to 'strengthen the unity of Africa under the rule of law' (PALU, 2006) - hinting at its pan-African vision and agenda. While Sooka and Khadiagala had brought in transitional justice expertise and an authoritative voice on the political economy of the pan-African project that is the AU and the network required to open the door to the AU, Deya's profile is foremost as an expert in the legal genre and discourse. He has been described as 'the most prolific litigator at the African Court on Human and Peoples' Rights (AfCHPR) and the East African Court of Justice (EACJ) ${ }^{28}$ and has an express interest in focusing on continental transitional justice efforts before drawing on international ones. ${ }^{29}$ Before heading PALU he was the Chief Executive of the 
East Africa Law Society, and Kenyan Section of the International Commission of Jurists (ICJ-Kenya), as well as Deputy CEO of the Law Society of Kenya (LSK). ${ }^{30}$ Besides supporting the revision of the AUTJP, PALU and Deya have also been involved in developing a model law for universal jurisdiction for the $\mathrm{AU}^{31}$ and drafted the Malabo Protocol. ${ }^{32}$

Deya thus contributed the legal expertise and understanding of the intricacies of policy development at the AU that was required when the STC asked for a review of the policy 'to make it more like a policy document' and less academic. The revised policy was then taken up again by the CSVR's Sufiya Bray, together with Brian Kagoro and Solomon Dersso, Commissioner at the African Commission for Human and People's Rights (ACommHPR), for further revision. ${ }^{33}$ Bray had been involved in the policy process from the side of the CSVR for several years. She was intimately familiar with the process and the key people and ideas it represents and accommodates. She too has a background in law. ${ }^{34}$ She allowed the expert assemblage to shift towards combining technical expertise with a familiarity with the people, the relationships involved in the process as it had unfolded, and the intentions that the civil society stakeholders had originally brought into the process. Brian Kagoro in turn is a pan-Africanist, constitutional and economic relations lawyer ${ }^{35}$ who has published about the AU and its organs, as well as the transition process in Zimbabwe (see for example Kagoro, 2002, 2008, 2012). He is an expert who is well versed in both the pan-African discourses that dominate much of the AU's policy and foreign relations debates, and the transitional justice discourses that take place at the intersection between mainstream global debates and particularistic African discourses. Dersso, being an expert in diversity management and constitutionalism, brought yet another profile to the table. He provided close linkages to key institutions within the AU institutional landscape, but also a deep understanding of the topics at hand, as well as the authorization to develop the ACommHPR's vision and understanding of transitional justice in Africa. ${ }^{36}$ Similar to the member states' delegates and representatives who participated in the policy process, Dersso represents a form of delegated authority as well as a thematic expert with considerable legal and policy expertise. He complements the technical and thematic expertise of Bray and Kagoro with the authority to shape the thinking of an AU organ on transitional justice and the authority of being a well-connected and respected member of the AU diplomatic and bureaucratic world.

Overall, this analysis describes and reflects on the different disciplinary backgrounds and profiles, as well as the nature of the expertise grounded in academic reflection or reflective practical experience working with transitional justice mechanisms, that were strategically assembled into this process. Throughout the different phases of the policy development different types of expertise were assembled through this practice of revision by key consultants 
to address the shifting requirements of the policy process. The first set of consultants (Khadiagala and Sooka) provided academic expertise in African governance and pan-Africanism, with the adjacent networks, combined with legally informed practico-technical expertise. When the need arose to polish the document into legalese and align it with the AU's policy format, prior expertise requirements were replaced by a need for legal expertise - based both on disciplinary background and experience - with the aim of making the policy look and feel 'more like a policy.' Following this, other issues highlighted by the STC had to be addressed (e.g. gender and youth) and the spirit of the document, from the perspective of civil society, had to be re-emphasized. In addition, to ensure adoption, $\mathrm{AU}$ and member state involvement in the process had to be strengthened further. Thus, the last set of 'reviewers' provided the combined expertise of an authorized policy-maker (Dersso) and the practico-technical and reflexive expertise required to see this process to its end (Kagoro and Bray). Working with consultant and external experts as reviewers rather than doing the revisions exclusively itself enabled the CSVR to draw on a broader set of experiences, networks and disciplinary insights. It thus legitimized the policy writing process by relying not on the expert status of one institution, the CSVR, but both the expertise and the expert status inferred on the consultants by regional and international actors, their academic status and the like. Assembling a changing set of experts allowed the CSVR to react to a changing process and permitted it to draw on various sources of authority and legitimacy both of which are key to the successful exercise of expertise.

\section{CONSULTATION MEETINGS: KNOWLEDGE PRODUCTION, CONTESTATION AND LEGITIMATION}

A second key strategy through which knowledge for this policy process was produced, assembled and legitimated was a series of 'consultation' and 'validation' meetings with transitional justice experts on the one side (AfricaNews. it, 2016; AU, 2016; Trust Africa et al., 2015; CSVR and AU, 2013) and 'member state experts/delegates/representatives' on the other side (AU and CSVR, 2011). While the consultation meetings with member states had 'capacity building components' (AU and CSVR, 2011) intended to strengthen member states' understanding of the issue of transitional justice, these meetings also aimed to provide space for debate, discussion and validation of the constantly evolving policy draft based on 'both academic and technical input' (Trust Africa et al., 2015: 11), thus drawing on the fact that transitional justice, like other fields, has two anchors: an academy and journal focused discipline, and 'an experience-centred discipline where lessons learned, training courses, policy research and the straddling of academic/practice divides are central' (Leander and Wæver, 2019: 6). 
Invited to these meetings were civil society (and governmental) stakeholders that could represent the different regions of the continent, ${ }^{37}$ the experience of African transitional justice researchers and practitioners, ${ }^{38}$ and legitimate voices for African transitional justice debates. The meetings thus served a threefold purpose: to familiarize AU member states with the debates, terminology and topic of transitional justice and 'breaking down all these assumptions around the discourse'; $; 9$ to debate, challenge and verify the policy and by implication the knowledge and expertise that went into it (CSVR, 2012; CSVR and AU, 2013). This process takes the form of a debate rather than a set body of knowledge from which relevant expertise would be drawn. The ATJRN had developed a starting point for this discussion with its comprehensive, African-authored critiques of mainstream transitional justice from an African perspective (e.g. Okello et al., 2012) and the insights it had gleaned from practice, research and joint critical reflection. Ideas from these critiques which shaped the policy draft were then put up for debate over years of consultations. This does not mean that some of the 'non-negotiables' as they have been referred to ${ }^{40}$ were dissolved, but rather that technical aspects, nuances, contextualization and the weighting of specific focus topics (e.g. gender and youth) were debated. Based on these deliberations and their own expertise, the consultants described above and the CSVR then revised the policy proposals accordingly.

While several of the key consultants and experts that drove the policy writing and revision process are lawyers, thus replicating many of the features of 'mainstream' transitional justice with its deep roots in legalism (McEvoy, 2007), the transitional justice expertise sought here transgresses the disciplines of international criminal and humanitarian law and human rights by inviting not only practitioners but also those with other disciplinary backgrounds (e.g. psychology, sociology, and others). Consultations can thus be read not only as an attempt to broaden the scope of the policy process and the experiences and expertise it draws from, but as a continental learning process (especially for member state representatives). It can also be seen as creating spaces for transdisciplinary perspectives and transferring these to policy spaces in order for transitional justice to go beyond judicial and quasi-judicial processes. From an assemblage perspective these broad consultations thus allowed and facilitated the emergence of transgressive expertise providing both new insights and additional legitimacy. An important dimension of this transgressive expertise is that it enabled the creation of connections between people and topics. As one process participant states, both the key experts and the consultation process allowed them to connect the policy process and topic to policy-makers' existing agendas ${ }^{41}$ in other words it helped them to connect the dots and pull together people and their interests into an overall strand of debate. 
However, while the consultation meetings inferred legitimacy on a set of core ideas they also opened space for the expertise to be seen as provisional and open to change. On the one side the core stakeholders who organized the consultation and policy process were opening themselves up to critique, indicating not only their acknowledgment that their expertise is limited and thus provisional - an acknowledgment that is increasingly being seen as a necessity for expertise to become recognized as such (Leander, 2018; Jasanoff, 2003) but they were also legitimating the policy outcome by increasing the ownership base of the process, thus democratizing the policy process to some extent. As one interviewee stated, 'obviously you're not going to get the draft anywhere if you come up as one civil society organization from one country. That's not going to work.' ${ }^{42}$ The outcome of the demonstrable ability to assemble these different forms of expertise and representations was thus a more legitimate policy document. ${ }^{43}$ They essentially put their policy proposal up for an extensive peer review, which is in itself a way of (re-)producing expertise (Leander, 2014), while simultaneously providing the opportunity to include new aspects of knowledge into the assemblage. By having drawn dozens of individuals and organizations into the policy process at various stages, the policy is arguably the result of a continental assemblage of experiences and expertise that represented and included voices from all regions of the continent. The consultation process thus helped to generate and assemble knowledge, but beyond that it was crucial for forging alignments, authorizing knowledge and legitimizing the policy outcome. The debated and negotiated character is not only central to the nature of expertise (Tan, 2019) that has been built here but it also conveys a sense of legitimacy onto the end product (Jasanoff, 2003), where there is 'consensus [between] the civil society organizations, the private sector and also the government saying that this is the policy that is needed and they accept it. So it is a legitimate document. ${ }^{44}$

In summary, the consultation meetings were one way of simultaneously debating and manifesting the cornerstones of the debate, thus stabilizing the knowledge at the core of the policy process. As one report describes them, the consultations were 'an opportune avenue for CSOs to engage constructively [with member state representatives, especially those of the STC task team] on the non-negotiable elements of the policy framework' (Trust Africa et al., 2015: 11). They were a means of folding further expertise into the assemblage that in turn helped broaden the knowledge and experience base that the policy could draw from, and they conferred additional legitimacy and authority onto the process by including a broader base of views and representations. However, as a side effect they can be presumed to have solidified the expert status of the CSVR as it was able to demonstrate not only an acknowledgment of the provisional nature and limits of its own expertise but also because 'expert status is the outcome of successful boundary work, then the expert is the one who is 
able to build a social network within which he or she is recognized as having relevant expertise' (Evans, 2016: 22).

\section{CONCLUSIONS}

This chapter has explored two practices employed by the CSVR and the AU in producing and assembling expertise, i.e. authoritative knowledge, for the problem of designing an AU transitional justice policy. I have selected two knowledge production practices that have helped the CSVR to simultaneously closely guide the policy debate at the AU while also opening it up by democratizing it and rendering it provisional and transgressive. I have chosen to look at two practices of consultation, through selected consultants and key experts on the one side, and a broader process of consultation meetings on the other side.

What emerges is a policy process that has been assembled from various professional practices and fields of knowledge, thus creating an assemblage of expertise. As has been shown, expert status for, and in, this process was derived equally from education, practical experience, networks, and international and regional acknowledgment of expert status. The assembled expertise is both academic and practice derived. It is at times both legalistic and political. Through its Africanness and regional representation of experiences it is particularistic but also universal in that it claims to be applicable in guiding countries and stakeholders across the continent and providing insights for challenging the globally dominant transitional justice paradigm beyond Africa. It is provisional in that it acknowledges its limits and temporary boundaries and (semi-)permanence in its form as a policy, i.e. as a minimum agreed consensus. Despite the assembled character of the expertise in this policy process, and unlike the expertise assemblages in other processes and fields that do not have a stable center (e.g. the counter-piracy field as discussed in Bueger, 2019), the CSVR clearly acted as the center of the assemblage of expertise for this policy process and in the course of the process also emerged as an important reference point in the African transitional justice discourse. Debating its own understanding of transitional justice while maintaining a clear strategic hold on the policy process helped it to maintain its expert status and influence, while simultaneously drawing on a consultative knowledge production process. Through this process and surrounding activities, the CSVR established itself as perhaps the continental hub on transitional justice expertise, including the knowledge, experience and the network required for that status. Nonetheless, the process did bring together different disciplinary backgrounds, and fields of practice, including academia, research, activism, policy-making, practice and advocacy. The process simultaneously accumulates African transitional justice expertise and sets, at least to some extent, its boundaries. 
Besides consultations, other knowledge production practices that were employed throughout the policy process - such as the commissioning of input papers and presentations, conducting research, producing resource packages, or knowledge transfer practices through a sustained learning approach - were equally important but are beyond the scope of this chapter and are of lesser importance to the points I have been trying to make here: namely that expertise is continuously assembled to meet the changing needs of a policy process. As such it is necessarily provisional, contested and exclusive - all of which also help to legitimize and authorize the same expertise. This also stresses that the need for expertise in a policy process can rarely be met by one (type of) actor as is often portrayed in the literature. Instead, expertise is multiple, strategic and assembled in a complex interplay of actors, and thus - within a given policy process - not 'owned by' one actor or organization. This undermines the finding of much of the existing transitional justice literature that international NGOs, as transitional justice experts, dominate transitional justice policy-making and agenda setting, and that they do so based on technical expertise. Further enquiries should thus be undertaken into the interplay and strategic use of different actors and knowledges as experts and expertise in transitional justice policy-making.

\section{NOTES}

1. The research for this article was kindly supported by a grant of the Swiss Program for Research on Global Issues for Development which is jointly funded by the Swiss Agency for Development and Cooperation (SDC) and the Swiss National Science Foundation (SNSF).

2. While the power Western actors hold over agenda setting and transitional justice practice in the Global South has frequently been pointed out, there are also a number of studies challenging this (presumed) dominance and highlighting instead the crucial role domestic Southern civil society and government actors play in transitional justice decision making, institutionalization and implementation. See Oduro and Nagy (2014) and Lamont et al. (2019).

3. Exceptions include 'Opportunities and Challenges of South-South Partnership: Reflections on a Collaborative Research Project on Violence and Transition in Africa' by van der Merwe et al. (2013).

4. Other intergovernmental institutions and international organizations, such as the EU (e.g. Rogacheva, 2019), the OSCE (e.g. Alawattage and Elshihry, 2017), OECD (e.g. Lemay-Hébert and Mathieu, 2014), NATO (e.g. Berling, 2016), the UN (e.g. Bierstecker, 2017; Bueger, 2015), or other policy areas in which expertise comes to bear, such as terrorism (e.g. Stampnitzky, 2014, 2016) or piracy (e.g. Bueger, 2018, 2019), have received greater attention.

5. The first was European Union's (2015) Transitional Justice Support Policy.

6. There was also concern from civil society actors who, for example, see the ICC's decisions and actions in tension with local peacebuilding efforts and at times the needs of victims (Glasius, 2009). 
7. The PoW is an organ of the APSA. However, the PSD, which is the secretariat of the APSA at the AUC, did not support the idea of developing a continental transitional justice policy. The policy then became the responsibility of the DPA (interview with civil society representative, 4 October 2018, Cape Town, South Africa).

8. A similar sentiment was expressed by several interviewees. E.g. interviews with civil society members on 4 October 2018, Cape Town, South Africa; on 10 March 2018, Cape Town, South Africa; and on 9 October 2018, Johannesburg, South Africa.

9. See the Refugee Law Project, accessed 29 March 2020 at https://www .refugeelawproject.org/

10. 'African Union Adopts Transitional Justice Policy', African Union Press Release, accessed 29 March 2020 at https://au.int/en/pressreleases/20190212/african-union -adopts-transitional-justice-policy

11. Substantive support was provided by Stephen Oola.

12. Interview with Gilbert Khadiagala, 9 October 2018, Johannesburg, South Africa.

13. See for example her appraisal by the Institute for Integrated Transitions: 'Yasmin Sooka', Institute for Integrated Transitions, accessed 29 March 2020 at https:// www.ifit-transitions.org/issue-areas/law-and-peace/law-and-peace-practice -group/yasmin-sooka

14. 'Yasmin Sooka', Institute for Integrated Transitions, accessed 29 March 2020 at https://www.ifit-transitions.org/issue-areas/law-and-peace/law-and-peace-practice -group/yasmin-sooka

15. 'Biographies of the Members of the Commission on Human Rights in South Sudan', accessed 8 August 2020 at https://www.ohchr.org/EN/HRBodies/HRC/ CoHSouthSudan/Pages/Bio.aspx

16. 'Yasmin Sooka', Open Society Foundations Boards, accessed 29 March 2020 at https://www.opensocietyfoundations.org/who-we-are/boards/human-rights -initiative-advisory-board/member/yasmin-sooka

17. 'Yasmin Sooka', Institute for Integrated Transitions, accessed 29 March 2020 at https://www.ifit-transitions.org/issue-areas/law-and-peace/law-and-peace -practice-group/yasmin-sooka

18. Interview with Gilbert Khadiagala, 9 October 2018, Johannesburg, South Africa.

19. Interview with former AU staff member, 19 February 2019, Addis Ababa, Ethiopia.

20. Interview with Gilbert Khadiagala, 9 October 2018, Johannesburg, South Africa.

21. Interview with Gilbert Khadiagala, 9 October 2018, Johannesburg, South Africa.

22. These efforts were complemented by the CSVR's own George Mukundi Wachira who also had considerable knowledge of and networks in the AU (interview with George Mukundi Wachira, 3 October 2018, Cape Town, South Africa; interview with Gilbert Khadiagala, 9 October 2018, Johannesburg, South Africa).

23. Interview with Salah Hammad, 21 February 2019, Addis Ababa, Ethiopia.

24. Interview with civil society representatives, 10 January 2019, Skype and 4 October 2018, Cape Town, South Africa.

25. Interview with civil society representative, 4 October 2018, Cape Town, South Africa.

26. Interview with civil society representative, 10 January 2019, Skype. For example, he led the drafting of the Malabo Protocol.

27. Interview with civil society representative, 4 October 2018, Cape Town, South Africa. See also Trust Africa et al. (2015). 
28. 'Profile: Don Deya', Never Again, accessed 29 March 2020 at https://neveragain .co.ke/profile-don-deya/article

29. 'Donald Daye [sic] African Juridictions and Transitionnal Justice', Thinking Africa, accessed 29 March 2020 at https://www.youtube.com/watch?v=J-LoZ $-A 2 P M Y$

30. 'Donald Deya', LinkedIn.com, accessed 29 March 2020 at https://www.linkedin .com/in/donald-deya-19b02632/

31. 'Donald Daye [sic] African Juridictions and Transitionnal Justice', Thinking Africa, accessed 29 March 2020 at https://www.youtube.com/watch?v=J-LoZ -A2PMY

32. Interview with civil society representative, Skype, 10 January 2019.

33. Interview with George Mukundi Wachira, 3 October 2018, Cape Town, South Africa. Interview with civil society representative, 19 August 2019, Cape Town, South Africa.

34. 'Sufiya Bray', LinkedIn.com, accessed 29 March 2020 at https://www.linkedin .com/in/sufiya-bray-75057422/?originalSubdomain=za

35. 'Brian Kagoro', Yale World Fellows Program, accessed 29 March 2020 at https:// worldfellows.yale.edu/brian-kagoro

36. In November 2015, Dersso had been appointed the Commissioner responsible for the Transitional Justice in Africa study which the ACommHPR commissioned (African Commission for Human and Peoples' Rights, 2015).

37. Interview with AU representative, 18 February 2019, Addis Ababa, Ethiopia.

38. Interview with civil society representative, 4 October 2018, Cape Town, South Africa.

39. Interview with civil society representative, 4 October 2018, Cape Town, South Africa; interview with Hugo van der Merwe, 10 March 2018, Cape Town, South Africa.

40. Interview with George Mukundi Wachira, 3 October 2018, Cape Town, South Africa.

41. Interview with Undine Whande, 10 December 2018, Skype.

42. Interview with Undine Whande, 10 December 2018, Skype.

43. Interview with AU representative, 6 December 2018, Skype.

44. Interview with AU representative, 6 December 2018, Skype.

\section{REFERENCES}

African Commission for Human and Peoples' Rights (2015), 'Resolution 326 on the Appointment of a New Commissioner for the Transitional Justice Study in Africa', 57th Ordinary Session in Banjul, The Gambia, 4-18 November 2015, ACHPR/ Res.326 (LVII) 2015.

African Commission for Human and Peoples' Rights (2019), Study on Transitional Justice and Human and Peoples' Rights in Africa, Banjul, The Gambia.

African Leadership Center (2018), 'Knowledge Production on Peace and Security in Africa. Mapping the Epistemic Terrain of Peace and Security in Africa (1960-2018)', accessed 30 March 2020 at https://alcafricandatalab.com/sites/default/files/ Knowledge\%20Production\%20on\%20Peace\%20and\%20Security\%20in\%20Africa .pdf

AfricaNews.it (2016), 'Continental Youth Consultation on the AU Transitional Justice Policy (AUTJP) in Nairobi, Kenya’, 10 November 2016, accessed 30 March 
2020 at http://www.africanews.it/english/continental-youth-consultation-on-the-au -transitional-justice-policy-autjp-in-nairobi-kenya/

Akokpari, J. (2008), 'Introduction. Human Rights Actors and Institutions in Africa', in J. Akokpari and D. S. Zimbler (eds), Africa's Human Rights Architecture, Johannesburg: Fanele, pp. 1-23.

Alawattage, C. and M. Elshihry (2017), 'The Managerialism of Neoliberal Global Governance. The Case of the OECD', in A. Littoz-Monnet (ed.), The Politics of Expertise in International Organizations. How International Bureaucracies Produce and Mobilize Knowledge, London and New York: Routledge Taylor \& Francis Group, pp. 166-87.

Ancelovici, M. and J. Jenson (2013), 'Standardization for Transnational Diffusion: The Case of Truth Commissions and Conditional Cash Transfers', International Political Sociology, 7 (3), 294-312.

ATJRN (2012), Report of the African Transitional Justice Research Network (ATJRN) Phase II (Project No. 105353-001), Johannesburg, South Africa.

AU (2009), 'Report of the African Union High Level Panel on Darfur (AUDP Report)', Peace and Security Council 207th Meeting at the Level of the Heads of State and Government, 29 October 2009, Abuja, Nigeria. PSC/AHG/2(CCVII).

AU (2016), 'Continental Experts Consultative Dialogue. Applying a Gender Lens to the Draft African Union Transitional Justice Policy', Press Release No. 415/2016, Addis Ababa, Ethiopia.

AU (2018), Fourth Ordinary Session of the Specialized Technical Committee on Justice and Legal Affairs (Ministerial Meeting), 30 November 2018, Addis Ababa, Ethiopia.

AU and CSVR (2011), 'African Union Commission Consultation with African Union Member States on Transitional Justice', Consultation Report, 12-13 September 2011, Addis Ababa, Ethiopia and Johannesburg, South Africa.

Bah, A. S., E. Choge-Nyangoro, S. Dersso, B. Mofya and T. Murithi (2014), The African Peace and Security Architecture. A Handbook, Addis Ababa: AU, Friedrich Ebert Foundation.

Berling, T. V. (2016), 'Tacit Expertise. How the NATO Defense College Nurtures an International Hub of Security Knowledge through Education', Eisenhower Paper 5, accessed 30 March 2020 at https://www.files.ethz.ch/isn/195657/Ep5.pdf

Berling, T. V. (2019), 'Stabilising Crises. Assembling NATO Defense College Expertise about Libya and Ukraine', in A. Leander and O. Wæver (eds), Assembling Exclusive Expertise. Knowledge, Ignorance and Conflict Resolution in the Global South, Abingdon: Routledge, pp. 93-109.

Best, J. (2014), 'Governing Failure', in Provisional Expertise and the Transformation of Global Development Finance, Cambridge: Cambridge University Press.

Bierstecker, T. (2017), 'Connecting Scholarly Expertise to International Policy Practice at the United Nations', in A. Littoz-Monnet (ed.), The Politics of Expertise in International Organizations. How International Bureaucracies Produce and Mobilize Knowledge, London and New York: Routledge Taylor \& Francis Group, pp. 111-27.

Bilgin, P. (2019), 'Worlding Conflict Resolution and Mediation Expertise', in A. Leander and O. Wæver (eds), Assembling Exclusive Expertise: Knowledge, Ignorance and Conflict Resolution in the Global South, Abingdon: Routledge, pp. 77-93.

Brankovic, J. (2010), 'Advocating Justice. Civil Society and Transitional Justice in Africa'. Workshop report, 30-31 August 2010, Johannesburg: CSVR. 
Brehm, H. N., C. Smith and E. Gertz (2019), 'Producing Expertise in a Transitional Justice Setting: Judges at Rwanda's Gacaca Courts', Law \& Social Inquiry, 44 (1), 78-101.

Bueger, C. (2015), 'Making Things Known: Epistemic Practices, the United Nations, and the Translation of Piracy', International Political Sociology, 9 (1), 1-18.

Bueger, C. (2018), 'Territory, Authority, Expertise: Global Governance and the Counter-Piracy Assemblage, European Journal of International Relations, 24 (3), 614-37.

Bueger, C. (2019), 'Experts in an Adventure with Pirates. A Story of Somali Piracy Expertise', in A. Leander and O. Wæver (eds), Assembling Exclusive Expertise: Knowledge, Ignorance and Conflict Resolution in the Global South, Abingdon: Routledge, pp. 40-56.

CSVR (2012), 'Expert's Review of African Transitional Justice Framework', Lome, Togo, 5 August 2012.

CSVR and AU (2013), 'Technical Experts' Consultation to Review the African Transitional Justice Policy Framework (ATJF), Nairobi, Nigeria, 29-31 August 2013.

Deng, F. M. (2013), 'Reconciling Sovereignty with Responsibility. A Basis for International Humanitarian Action', in J. W. Harbeson (ed.), Africa in World Politics. Engaging a Changing Global Order, Boulder, CO: Westview Press, pp. 310-49.

Deng, F. M., S. Kimaro, T. Lyons, D. Rothchild and I. T. Zartman (1996), Sovereignty as Responsibility. Conflict Management in Africa, Washington, DC: Brookings Institution Press.

European Union (2015), The EU's Policy Framework on Support to Transitional Justice, Brussels: European Union.

Evans, R. (2016), 'What is Expertise? Technical Knowledge and Political Judgement', in T. V. Berling and C. Bueger (eds), Security Expertise. Practice, Power, Responsibility, Abingdon and New York: Routledge, pp. 19-36.

Fletcher, L. E. and H. M. Weinstein (2018a), 'How Power Dynamics Influence the "North-South" Gap in Transitional Justice', Berkeley Journal of International Law, $37(1), 1-28$.

Fletcher, L. E. and H. M. Weinstein (2018b), "North-South" Dialogue: Bridging the Gap in Transitional Justice. Workshop Transcript', Berkeley Journal of International Law, 37 (1), 29-144.

Gawanas, B. (2009), 'The African Union. Concepts and Implementation Mechanisms Relating to Human Rights', in A. Bösl and J. Diescho (eds), Human Rights in Africa. Legal Perspectives on their Protection and Promotion, Windhoek: Konrad Adenauer Stiftung, pp. 135-62.

Glasius, M. (2009), 'What is Global Justice and Who Decides? Civil Society and Victim Responses to the International Criminal Court's First Investigations', Human Rights Quarterly, 31 (2), 496-520.

Gomes Porto, J. and K. Y. Ngandu (2014), 'The African Union, Preventive Diplomacy, Mediation, and the Panel of the Wise: Review and Reflection on the Panel's First Six Years', African Security, 7 (3), 181-206.

Haas, P. M. (1992), 'Introduction: Epistemic Communities and International Policy Coordination', International Organization, 46 (1), 1-35.

Hamber, B. (2008), Evaluation of the African Transitional Justice Research Network, Coleraine: International Conflict Research Institute. 
Hanzi, R. (2010), 'Reparations and the African Commission. Experiences from Zimbabwe', CSVR Report, accessed 30 March 2020 at https://www.csvr.org.za/images/NewSept2010/ 10_Roselyn\%20Hanzi_Reparations\%20and\%20the\%20African\%20Commission $\% 20$ $\%$ 20Eperiences\%20from $\% 20$ Zimbabwe.pdf

Humphrey, A. and RLP (2014), The Fourth Institute for African Transitional Justice Report (IATJ): Global Transitions, Africa's Resource Riches, and the Future of Transitional Justice, Kampala: Refugee Law Project.

International Criminal Court (2009), 'The Prosecutor v. Omar Hassan Ahmad Al Bashir, ICC-02/05-01/09', accessed 30 March 2020 at https://www.icc-cpi.int/ darfur/albashir

Jasanoff, S. (2003), '(No?) Accounting for Expertise', Science and Public Policy, 30 (3), 157-62.

Kagoro, B. (2002), 'Can Apples be Reaped from a Thorn Tree? A Case Analysis of the Zimbabwean Crisis and NEPAD's Peer Review Mechanism', presented to the Southern Africa Research Poverty Network (SARPN) and Center for Civil Society, Durban, South Africa.

Kagoro, B. (2008), Chaos and Transition in Zimbabwe. Transformation or Mirage? Harare: Prestige Books.

Kagoro, B. (2012), 'The Paradox of Alien Knowledge, Narrative and Praxis. Transitional Justice and the Politics of Agenda Setting in Africa', in M. C. Okello, C. Dolan, U. Whande, N. Mncwabe, L. Onegi and S. Oola (eds), Where Law Meets Reality. Forging African Transitional Justice, Cape Town, Dakar, Nairobi and Oxford: Pambazuka Press, pp. 4-52.

Keck, M. and K. Sikkink (1998), Activists Beyond Borders. Advocacy Networks in International Politics, Ithaca, NY: Cornell University Press.

Khadiagala, G. M. (2012), 'The Role of the African Union, New Partnership for Africa's Development, and African Development Bank in Postconflict Reconstruction and Peacebuilding', in D. Curtis and G. A. Dzinesa (eds), Peacebuilding, Power, and Politics in Africa, Athens: Ohio University Press.

Khadiagala, G. M. (2015), 'Silencing the Guns. Strengthening Governance to Prevent, Manage, and Resolve Conflicts in Africa', International Peace Institute, accessed 30 March 2020 at https://www.files.ethz.ch/isn/191033/IPI_Rpt-Silencing_the_Guns -Strengthening_Governance_Africa.pdf

Khadiagala, G. M. (2018), 'Regional Cooperation on Democratization and Conflict Management in Africa', Carnegie Endowment for International Peace, accessed 30 March 2020 at https://carnegieendowment.org/2018/03/19/regional-cooperation-on -democratization-and-conflict-management-in-africa-pub-75769

Klingebiel, S. (2005), 'Africa's New Peace and Security Architecture. Converging the Roles of External Actors and African Interests', African Security Review, 14 (2), $35-44$.

Knorr-Cetina, K. (2001), 'Objectual Practice', in T. R. Schatzki, K. Knorr-Cetina and E. von Savigny (eds), The Practice Turn in Contemporary Theory, London and New York: Routledge, pp. 175-88.

Knorr-Cetina, K. (2008), 'Theoretischer Konstruktivismus. Über die Einnistung von Wissenstrukturen in Soziale Strukturen', in H. Kalthoff, S. Hirschauer and G. Lindemann (eds), Theoretische Empirie. Zur Relevanz Qualitativer Forschung, Frankfurt am Main: Suhrkamp, pp. 35-78.

Lamont, C. K., J. R. Quinn and E. Wiebelhaus-Brahm (2019), 'The Ministerialization of Transitional Justice', Human Rights Review, 20 (1), 103-22. 
Leander, A. (2013), 'Technological Agency in the Co-Constitution of Legal Expertise and the US Drone Program', Leiden Journal of International Law, 26 (4), 811-31.

Leander, A. (2014), 'Essential and Embattled Expertise. Knowledge/Expert/Policy Nexus around the Sarin Gas attack in Syria', Politik, 17 (2), 26-37.

Leander, A. (2018), 'International Relations Expertise at the Interstices of Fields and Assemblages', in A. Gofas, I. Hamati-Ataya and N. Onuf (eds), The SAGE Handbook of the History, Philosophy and Sociology of International Relations, London: SAGE Publications, pp. 386-98.

Leander, A. and O. Wæver (2019), 'Introduction. Assembling Exclusive Expertise: Knowledge, Ignorance, and Conflict Resolution in the Global South', in A. Leander and O. Wæver (eds), Assembling Exclusive Expertise: Knowledge, Ignorance and Conflict Resolution in the Global South, Abingdon: Routledge, pp. 1-20.

Lefranc, S. and F. Vairel (2013), 'The Emergence of Transitional Justice as a Professional International Practice', in L. Israël and G. Mouralis (eds), Dealing with Wars and Dictatorships: Legal Concepts and Categories in Action, The Hague: T. M. C. Asser Press, pp. 235-52.

Lemay-Hébert, N. and X. Mathieu (2014), 'The OECD's Discourse on Fragile States: Expertise and the Normalisation of Knowledge Production', Third World Quarterly, 35 (2), 232-51.

Li, T. M. (2007), 'Practices of Assemblage and Community Forest Management', Economy and Society, 36 (2), 263-93.

Lugano, G. (2017), 'Counter-Shaming the International Criminal Court's Intervention as Neocolonial: Lessons from Kenya', International Journal of Transitional Justice, 11 (1), 9-29.

Madlingozi, T. (2010), 'On Transitional Justice Entrepreneurs and the Production of Victims', Journal of Human Rights Practice, 2 (2), 208-28.

Mathews, K. (2008), 'Renaissance of Pan-Africanism. The AU and the New Pan-Africanists', in J. Akokpari, A. Ndinga-Muvumba and T. Murithi (eds), The African Union and its Institutions, Johannesburg: Fanele and Centre for Conflict Resolution, pp. 25-40.

McEvoy, K. (2007), 'Beyond Legalism: Towards a Thicker Understanding of Transitional Justice', Journal of Law and Society, 34 (4), 411-40.

Mouralis, G. (2013), 'The Invention of "Transitional Justice” in the 1990s', in L. Israël and G. Mouralis (eds), Dealing with Wars and Dictatorships: Legal Concepts and Categories in Action, The Hague: T. M. C. Asser Press, pp. 83-100.

Murithi, T. (2013), The African Union and the International Criminal Court. An Embattled Relationship? Cape Town: Institute for Justice and Reconciliation.

Murithi, T. (2017), Africa and the Remaking of Global Order, Cape Town: Institute for Justice and Reconciliation.

Mwanasali, M. (2008), 'From Non-Interference to Non-Indifference. The Emerging Doctrine of Conflict Prevention in Africa', in J. Akokpari, A. Ndinga-Muvumba and T. Murithi (eds), The African Union and its Institutions, Johannesburg: Fanele and Centre for Conflict Resolution, pp. 41-62.

Ní Aoláin, F. (2015), 'Southern Voices in Transitional Justice. A Critical Reflection on Human Rights and Transition', in U. Baxi, C. McCrudden and A. Paliwala (eds), Law's Ethical, Global and Theoretical Contexts. Essays in Honour of William Twining, Cambridge: Cambridge University Press, pp. 73-89.

Nowotny, H. (2000), 'Transgressive Competence', European Journal of Social Theory, $3(1), 5-21$. 
Oduro, F. and R. Nagy (2014), 'What's in an Idea? Truth Commission Policy Transfer in Ghana and Canada', Journal of Human Rights, 13 (1), 85-102.

Okello, M. C., C. Dolan, U. Whande, N. Mncwabe, L. Onegi and S. Oola (2012), Where Law Meets Reality. Forging African Transitional Justice, Cape Town, Dakar, Nairobi and Oxford: Pambazuka Press.

Oomen, B. (2005), 'Donor-Driven Justice and its Discontents: The Case of Rwanda', Development and Change, 36 (5), 887-910.

PALU (2006), Memorandum of Understanding Establishing the Framework for Cooperation and Collaboration between the African Union and the Pan African Lawyers Union, signed in Dakar on 8 May 2006, Dakar, Senegal.

Panel of the Wise (2013), 'Peace, Justice, and Reconciliation in Africa. Opportunities and Challenges in the Fight Against Impunity', Report of the AU Panel of the Wise, New York: International Peace Institute.

Rogacheva, A. (2019), 'The Demand for Advice at the European Union Level: Policy Advice Politicization in the European Commission', Policy Studies, 80 (4), 1-18.

Songa, A. (2018), Transitional Justice in Kenya as a Path to Transformation, Cape Town: CSVR.

Ssenyonjo, M. (2013), 'The Rise of the African Union Opposition to the International Criminal Court's Investigations and Prosecutions of African Leaders', International Criminal Law Review, 13 (2), 385-428.

Stampnitzky, L. (2014), Disciplining Terror. How Experts Invented 'Terrorism', Cambridge: Cambridge University Press.

Stampnitzky, L. (2016), 'Problematic Knowledge. How “Terrorism” Resists Expertise', in T. V. Berling and C. Bueger (eds), Security Expertise. Practice, Power, Responsibility, Abingdon and New York: Routledge, pp. 158-71.

Subotic, J. (2012), 'The Transformation of International Transitional Justice Advocacy', International Journal of Transitional Justice, 6 (1), 106-25.

Tan, S. S. (2019), 'The "Singapore School" and the Contested Enterprise of Terrorism', in A. Leander and O. Wæver (eds), Assembling Exclusive Expertise: Knowledge, Ignorance and Conflict Resolution in the Global South, Abingdon: Routledge, pp. 110-26.

Trust Africa, CSVR and MacArthur Foundation (2015), 'The Road to Establishing an African Transitional Justice Architecture', Expert Consultation Meeting Report, 19-20 November 2015, Cape Town, South Africa.

van der Merwe, H., N. Rousseau, N. Marekia, P. Machakanja and E. Bere (2013), 'Opportunities and Challenges of South-South Partnership. Reflections on a Collaborative Research Project on Violence and Transition in Africa', AfricaPortal, accessed 30 March 2020 at https://www.africaportal.org/publications/opportunities -and-challenges-of-south-south-partnership-reflections-on-a-collaborative-researchproject-on-violence-and-transition-in-africa/

Wachira, G. M. (2010), 'Advocating for the Adoption of a Holistic Transitional Justice Policy at the African Union', African Transitional Justice Research Network Workshop 'Advocating Justice: Civil Society and Transitional Justice in Africa', 30-31 August 2010, accessed 30 March 2020 at https:/www.csvr.org.za/images/NewSept2010/11 George $\% 20$ Mukundi\%20Wachira_Advocating\%20for\%20the\%20Adoption $\% 20$ of $\overline{\%} 20 \mathrm{a} \% 20$ Holistic\%20Transitional $\%$ 20Justice\%20Policy\%20at\%20the $\% 20$ African $\%$ 20Union.pdf 